\title{
BILATERAL CORTICAL ATROPHY AFTER SEVERE BRAIN TRAUMA AND EXTRADURAL HEMATOMA
}

\author{
Paulo Roberto Louzada', Rafael Pereira Vaitsman², \\ Arthur Borges Martins de Souza ${ }^{3}$, Pedro de Oliveira Coutinho 4 , \\ Renata Teixeira Lengruber ${ }^{5}$, Francisco Weldes Brito das Neves', \\ Herbert Missaka7, Marco Aurélio Albuquerque Lima7, José Massoud Salame ${ }^{8}$
}

\begin{abstract}
We report the case of a severe head injured 43-year old male patient with a large extradural hematoma, Glasgow Coma Scale 3 and dilated fixed pupils. Patient was promptly submitted to surgical evacuation of the lesion, but remained in persistent vegetative state in the post-operative time. Head computed tomography scans performed before surgery, and at early and late post-operative periods comparatively revealed extreme bilateral cortical atrophy. Late consequences of severe head trauma drastically affect the prognosis of patients, being its prevention, and neuroprotection against secondary injury still a therapeutical challenge for neurosurgeons.
\end{abstract}

KEY WORDS: brain atrophy, extradural hematoma, epidural hematoma, severe head injury, secondary injury.

\begin{abstract}
Atrofia cortical bilateral após traumatismo cranioencefálico grave e hematoma extradural
RESUMO - Relatamos o caso de um paciente de 43 anos, com traumatismo cranioencefálico grave, com grande hematoma extradural, Escala de Coma de Glasgow 3 e pupilas fixas e dilatadas. O paciente foi prontamente submetido à evacuação cirúrgica da lesão mas permaneceu em estado vegetativo persistente no período pós-operatório. As TC de crânio realizadas antes da cirurgia e nos períodos pós-operatórios precoce e tardio revelaram comparativamente extrema atrofia cerebral bilateral. As conseqüências tardias do traumatismo craniano grave afetam drasticamente o prognóstico dos pacientes, sendo sua prevenção, e a neuroproteção contra a injúria secundária ainda um desafio terapêutico para os neurocirurgiões.
\end{abstract}

PALAVRAS-CHAVE: atrofia cerebral, hematoma extradural, hematoma epidural, traumatismo craniano grave, injúria secundária.

Extraaxial hematomas, extradural hematoma (EH) and subdural hematoma (SH), stand among the most common neurosurgical emergencies in general hospitals worldwide. Prognosis and mortality rates of patients with extra-axial hematomas are clearly dependent on neurological status on admittance' ${ }^{\prime}$. Literature reports a mortality rate of $4.7 \%$ for patients with extradural hematoma operated at Glasgow Coma Scale (GCS) $13-15$, with $66.7 \%$ of good recovery, ranging to a mortality rate of $43 \%$, and only $29 \%$ of good recovery for patients admitted at GCS 3-8'. In this line, Kotwica and Jakubowski studied brain injured patients admitted in GCS 3, reporting an overall mortality of
$89 \%^{2}$. In the same study, better outcomes for GCS 3 patients were reached for those with no abnormalities on CT scan or for patients with extradural hematoma surgically treated ${ }^{2}$. Better prognosis is obtained when surgical evacuation is performed early after trauma, as classically described for $\mathrm{SH}$, when surgery is performed within the first four hours after trauma ${ }^{3}$.

We present a case of a severe head injured patient with a large $\mathrm{EH}$, operated in less that 1 hour after admission, evolving to vegetative persistent state and radiological evidences of delayed bilateral brain atrophy several weeks after surgery. Bilateral post-trau-

\footnotetext{
'MD, PhD, Neurosurgeon, Serviço de Neurocirurgia, Hospital Municipal Souza Aguiar, Rio de Janeiro RJ, Brazil; ${ }^{2} \mathrm{MD}$, Neurosurgery Resident, Serviço de Neurocirurgia, Hospital Municipal Souza Aguiar, Rio de Janeiro RJ, Brazil; ${ }^{3}$ MD, Neurosurgeon, Serviço de Neurocirurgia, Instituto Nacional de Câncer (INCA). Rio de Janeiro, RJ, Brazil; 'MDD, Neurosurgery Resident, Serviço de Neurocirurgia, Hospital Municipal Souza Aguiar, Rio de Janeiro RJ, Brazil; 5 Neurology Resident, Serviço de Neurologia, Hospital Universitário Antônio Pedro, Universidade Federal Fluminense, Niterói RJ, Brazil; ${ }^{6} \mathrm{MD}$, Neurosurgeon, Serviço de Neurocirurgia, Hospital Municipal Souza Aguiar, Rio de Janeiro RJ, Brazil; ${ }^{7} \mathrm{MD}$, ICU Physician, Unidade de Pacientes Graves (UPG / CTI - Emergência), Hospital Municipal Souza Aguiar, Rio de Janeiro, RJ, Brazil; ${ }^{8}$ MD, Neurosurgeons, Serviço de Neurocirurgia, Hospital Municipal Souza Aguiar, Rio de Janeiro RJ, Brazil. Support: Prefeitura Municipal do Rio de Janeiro.
}

Received 31 May 2007. Accepted 12 September 2007.

Dr. Paulo Roberto Louzada - Serviço de Neurocirurgia / Hospital Municipal Souza Aguiar - Praça da República 111 / $4^{\circ}$ andar - 20211-350 Rio de Janeiro RJ - Brasil. E-mail: louzada20o7@yahoo.com.br 
matic brain atrophy is an uncommon event, with few descriptions in the literature and no efficient treatment currently available to preclude such condition. We discuss the possible relation of the poor post-operative outcome with the radiological findings of brain atrophy highlighting the consequences of secondary brain injury.

\section{CASE}

A 43-year old man, probably victim of aggression, was admitted to the emergency room with a history of rapid neurological deterioration from GCS 6 (at the ambulance) to GCS 3 within the past 30 minutes. Patient was intubated and no respiratory drive was detected. Pupils were dilated and fixed. CT scan performed 10 minutes after admission revealed a huge $(4.2 \mathrm{~cm})$ left extradural temporo-parietal hematoma with significant $(1.6 \mathrm{~cm})$ midline shift (Fig 1A and $1 \mathrm{D})$. The patient was promptly conducted to operating room. A large fronto-temporo-parietal incision was made to access the entire lesion. A skull fracture was identified crossing a branch of middle meningeal artery, being implicated as the cause of the hemorrhagic lesion. A temporo-parietal craniectomy was performed with complete evacuation of the lesion in less than 1 hour after patient admittance in the hospital. In the immediate post-operative period, patient mildly ameliorate its neurological status from bilateral midriasis to anisocoria (left > right), being conducted to the intensive care unit for post-operative support.

A CT scan performed 48 hours after surgery reveals entire evacuation of the hematoma, improvement of midline shift and signs of left parietal ischemic injury by compression of underlying neural tissue (Fig $1 \mathrm{~B}$ and $1 \mathrm{E}$ ). Pupillary reactivity became normal after several weeks, when patient was awake but unresponsive to any stimuli, thus characterizing a persistent vegetative state.

Four months and eleven days after surgery, a new CT scan were made to access any late complication of the head trauma responsible for the patient unresponsiveness. Interestingly, remarkable bilateral brain atrophy (Fig ${ }_{1} \mathrm{C}$ and ${ }_{1} \mathrm{~F}$ ) was observed. Enlarged sulci were more predominant in the fronto-temporal lobes than in right parietal and occipital lobes. Patient has no history of alcoholism or other predisposing condition to cortical atrophy before head trauma. Encefalomalacia and ventricular occipital horn ectasia could be observed at left hemisphere, consequent to ischemic insult already observed in the first post-op exam. Patient remained in persistent vegetative state and died near six months after surgery from pulmonary sepsis and respiratory failure.

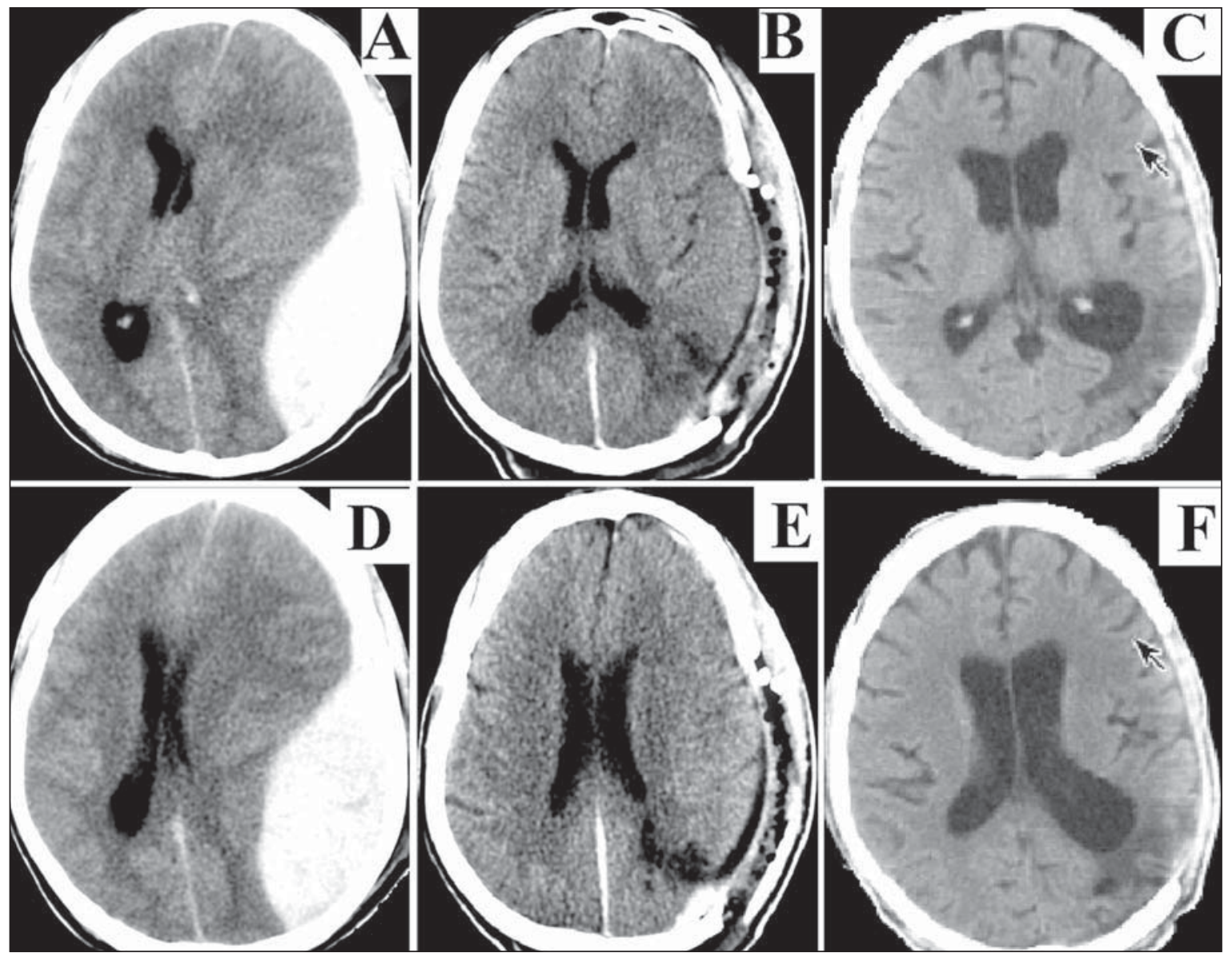

Fig 1. CT scans showing large parietal left extradural hematoma ( $A$ and $D)$. B and $E$, immediate post op CT scan: complete evacuation of the lesion by craniectomy. $C$ and $F$, delayed cerebral atrophy in the exam performed about four months after surgery. 


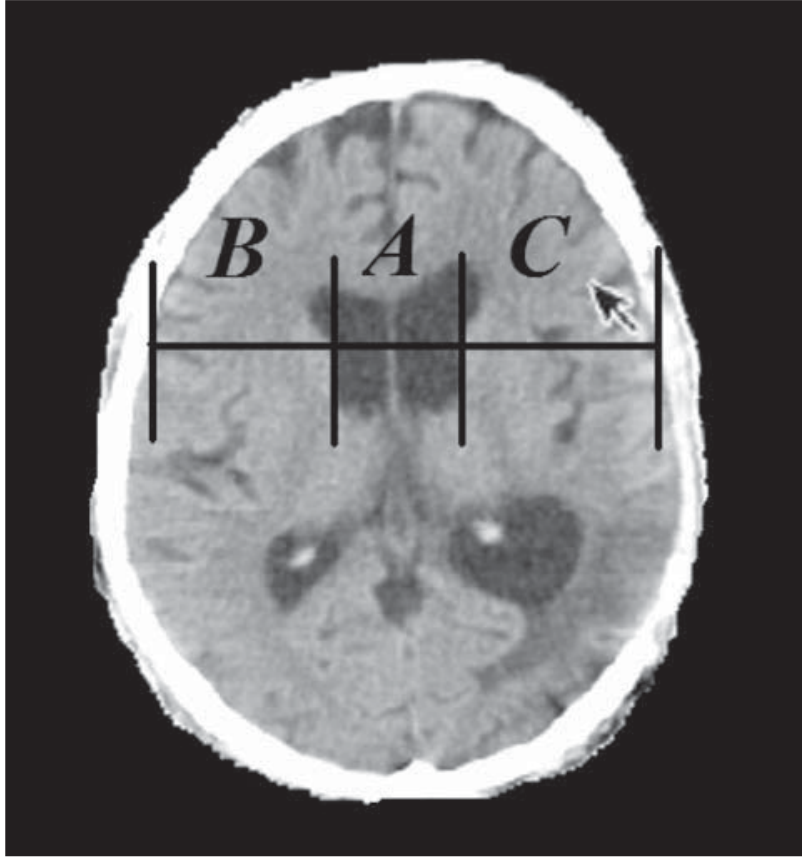

Fig 2. Data for the calculation of bicaudate cerebroventricular index (BCVI). $A$, width of frontal horns. $A+B+C$, width of both hemispheres at the head of caudate nucleus level. $B C V I=$ $(A / A+B+C) \times 100$.

\section{DISCUSSION}

Bilateral cerebral atrophy secondary to brain trauma are an uncommon finding, poorly reported in the literature. Levin et al. report two cases of children with reversible cerebral atrophy years after a $\mathrm{SH}^{4}$. Tomita et al. showed a large series of delayed hemispheric brain atrophy after $\mathrm{EH}$ and $\mathrm{SH}^{5}$. In this study, authors reported that from 42 patients victims of neurotrauma, only $9(21 \%)$ presented enlarged ventricles and cerebral atrophy 5 . More recently, Mackenzie et al. presented a retrospective study of patients with closed, mild to moderate head injury that evolved to whole brain atrophy at an average time of 11 months ${ }^{6}$.

We demonstrated a case of severe head injured patient evolved to secondary bilateral brain atrophy about four months after trauma. Brain atrophy is defined as enlarged lateral ventricles with prominent cerebral sulci,8. In our study, the size of the lateral ventricles was measured using the the bicaudate cerebroventricular index (BCVI) on the CT scan taken in the plane parallel to orbitomeatal line as demonstrated by Tomita et al. ${ }^{5}$. The BCVI was measured by the ratio between the width of the ventricular frontal horns and the total width of the two brain hemispheres measured at the head the caudate nucleus level ${ }^{5}$. Figure 2 , indicates the measures $A, B$ and $C$, to obtain BCVI by the formula $(A / A+B+C) \times 100$.
The normal reported $\mathrm{BCVI}$ in adults is $15 \pm 3 \%$. Values higher than $18 \%$, in the presence of enlarged sulci, are considered to be indicative of cerebral atrophy. In the series of Tomita et al. the higher BCVI obtained in a patient victim of $\mathrm{EH}$ was $24.6 \%^{5}$. In the case reported here, we obtained a BCVI of $25.5 \%$, confirming the larger bilateral cerebral atrophy caused by an $\mathrm{EH}$ reported in the literature.

Secondary brain injury, the sequence of pathophysiological and intracellular events that follows primary mechanical damage to the neural tissue, has been extensively studied, however the precise mechanisms underlying secondary brain injury remains still unclear. Delayed neural injury may results from neurochemical imbalances (mainly excitotoxicity), neuroinflammation, oxidative stress etc ${ }^{9}$. Apoptotic cell death and ischemia, two biological events related to secondary brain injury, among others, was already reported to be involved in posttraumatic neurodegeneration and neuroatrophy ${ }^{5,6}$. In the case described here, neuronal loss occurs bilaterally, mainly at the cerebral cortex but also at the brainstem and cerebellum (not shown), therefore away from the site of the lesion (left temporal-parietal lobes), thus, could not be explained simply by the effects of direct neural tissue compression, being probably due to secondary and late toxic neurochemical and neuroinflammatory phenomena affecting the whole brain.

Brain atrophy could be, in part, responsible for the devastating neurological sequelae presented by the patient reported in this case, once delayed neuroanatomical changes were more predominant in the bifrontal and bitemporal cortices, leading to a compromising of cognition and motor function. Moreover, the intensity if neuronal loss observed (BCVI 25.5\%) could be closely related to the severity of neurological status presented by the patient on admission (GCS 3, dilated and fixed pupils).

Encouraging therapeutical strategies against secondary brain injury has been investigated in clinical trials $s^{2,10}$. However, currently, there is no treatment able to block secondary brain injury and the delayed cerebral atrophy. Once the full mechanisms of neural damage after primary insult can be elucidated, neuroprotective strategies must to be developed to improve outcome of severe brain damaged patients.

\section{REFERENCES}

1. Cheung PS, Lam JM, Yeung JH, Graham CA, Rainer TH. Outcome of traumatic extradural haematoma in Hong Kong. Injury 2007;38:76-80.

2. Kotwica Z, Jakubowski JK. Head-injured adult patients with GCS of 3 on admission--who have a chance to survive ? Acta Neurochir (Wien) 1995;133:56-59. 
3. Seelig JM, Becker DP, Miller JD, Greenberg RP, Ward JD, Choi SC. Traumatic acute subdural hematoma: major mortality reduction in comatose patients treated within four hours. N Engl J Med 1981;304:1511-1518.

4. Levin HS, Mendelsohn D, Bruce D, Harward H, Culhane KA, Eisenberg $\mathrm{HM}$. Reversibility of cerebral atrophy after head injury in children. Neurosurgery 1992;31:1117-1121.

5. Tomita $\mathrm{H}$, Tone $\mathrm{O}$, Ito U. Hemispheric cerebral atrophy after traumatic extra-axial hematoma in adults. Neurol Med Chir (Tokyo) 1997; 37:819-824.

6. MacKenzie JD, Siddiqi F, Babb JS, et al. Brain atrophy in mild or moderate traumatic brain injury: a longitudinal quantitative analysis. Am J Neuroradiol 2002;23:1509-1515.
7. Kishore PR, Lipper MH, Miller JD, Girevendulis AK, Becker DP, Vines FS. Post-traumatic hydrocephalus in patients with severe head injury. Neuroradiology 1978;16:261-265.

8. Synek V, Reuben JR, Du Boulay GH. Comparing Evans' index and computerized axial tomography in assessing relationship of ventricular size to brain size. Neurology 1976;26:231-233.

9. McIntosh TK, Smith DH, Garde E. Therapeutic approaches for the prevention of secondary brain injury. Eur J Anaesthesiol 1996;13:291-309.

10. Clausen T, Bullock R. Medical treatment and neuroprotection in traumatic brain injury. Curr Pharm Des 2001;7:1517-1532. 